The discovery of atebrin soon followed. This proved to be a valuable drug for prophylactic use in the Second World War. Still more potent drugs, chloroquine and amodiaquine, were isolated shortly afterwards. These two are excellent, having a complete prophylactic action against almost all forms of malaria, while producing no side-effects. Two further anti-malarials to be discovered were proguanil and pyrimethamine ('Daraprim'), the latter being particularly long-lasting. It was discovered by George Hitching of the Burroughs Wellcome Laboratories.

The conquest of malaria has also been greatly assisted through the use of insecticides, such as pyrethrum, Paris green, benzene hexachloride (BHC) and DDT. In the case of some of these there was long delay between their first discovery and exploitation. BHC, for example, was isolated by Faraday in 1825, yet its insecticidal properties were only discovered in the United States in 1933; and a German chemist, Zeidler, synthesized. DDT in 1874, yet its properties as an insecticide were first noticed by Paul Müller in the Geigy Laboratories, in Basle, in 1939. The Second World War did a great deal to stimulate the production and exploitation of these compounds. As an example of insecticidal potency, one might mention BHC, which six months after application on mud walls is capable of killing 80 per cent of Anopheles gambiae.

Taken together, all these developments have completely transformed the situation in rolation to the conquest of malaria. In Nyasaland, for example, as late as 1897, the death rate among European settlers averaged between 9 and 10 per cent, mainly from fever, in a young population. In Northern Rhodesia, during 1907 08, the death rate from malaria and blackwater fever combined was $30 \cdot 4$ per 1,000 ; in 1925 , even before the aforementioned developments, it had fallen to $2 \cdot 8$.

Such results can be compared with those associated with the construction of the Kariba Dam, which was started in 1956 and completed by 1960. Not once was work held up or even interrupted because of disease. This huge under- taking involved the importation of enormous numbers of African workers from many parts of the country and the employment of many Europeans who had not previously built up any immunity through exposure to malaria. For health and comfort, the living quarters were placed on high ground. All workers were informed about the dangers of heat stroke, and employers were encouraged to allow their workers a period for acclimatization. A survey of the locality showed a spleen rate of 80 per cent, and a parasite rate of more than 30 per cent among the original, local community. All the interior walls of dwellings were sprayed with $\mathrm{BHC}$, and this procedure was repeated three times a year.

As a preliminary measure, an attack was made against mosquito breeding-places through spraying with 'High Spread Malariol' (Shell). Survey counts showed that the operation was effective, so that there was no need to repeat it later. All workers were required to take the prophylactic drug with which they were provided-at first, $0.4 \mathrm{~g}$ of camoquin weekly for the Europeans, and $100 \mathrm{mg}$ of mepacrin for the Africans. Later, daraprim was substituted at the rate of $25 \mathrm{mg}$ each per week.

All windows of the European houses were screened, and this helped to keep away millions of other insects as well as mosquitoes. As a consequence, there was not one death from malaria among Europeans living on the site during the first two years. There were two deaths, however, of men living in temporary camps outside the recognized limits, and nearly all the European cases of fever gave a. history of irregular prophylaxis, or fishing or hunting at night beyond the controlled area.

These results show that apart from human factors, in Central Africa the conquest of malaria is now almost complete. They also show that in Africa it is a mistake to think of medicine in terms of individual territories.

\section{R. Weatherall}

${ }^{1}$ Gelfand, M., Rivers of Death (Supplement to The Central African Journal of Medicine, 11, No. 8; August, 1965).

\title{
APPLIED SCIENCE IN THE SCHOOLS
}

$\mathrm{I}^{\mathrm{N}}$ recent years a recurrent theme in discussions of science teaching has been the inability of courses in applied science and engineering at universities to attract the best students. This has led to a good deal of self-analysis and exposition of their aims by engineers, and to attempts to acquaint science and careers masters with the nature and purposes of these courses. More fundamental questions are those concerned with changes in the nature of school science teaching itself, and some of the great interest in the new pure science syllabuses of the past few years has now shifted to the possible introduction of applied science courses at school level. This concern led the Institution of Mechanical Engineers* to ask Mr. G. T. Page to assemble a report on the present situation in schools, and in a very short time he produced a mass of information and ideas, obtained both by direct visits and by a postal survey, collated, compared and summarized into an urgent, highly relevant volume.

A conference in October, to discuss this report, showed a very high degree of interest in the whole subject and also produced very complimentary estimates of the report itself, and it is certain that it is at present exercising headmasters and many educational authorities throughout the country. Mr. Page labels his book as descriptive rather than prescriptive, and a large part of the 328 pages is taken up with detail of what is done in a number of schools, both in terms of actual teaching of applied science and 'application-conscious' teaching of physics and chemis-

* 'The Institution of Mechanical Engineers: Enyineering Among the Schools : Activities in Applied Science and Engineering-a Survey of 290 Schools. try, with syllabuses, details of projects, costing and much more important information, both in the text and in appendixes. A lot of space is devoted to the best known experiments in the field, such as the Technical Activities Centre at Sevenoaks School, the examined project work at Dauntsey's School, and the sixth-form courses in applied science such as that at Ealing Grammar School. However, the report is much better regarded as a digest of many different opinions about, and aspects of, the whole subject. There are, for example, chapters on "Engineers as Teachers" and "Workshop and Laboratory Technical Assistance", and a provocative section called "What the Universities Really Think", in which the widely different views of many authorities are contrasted. Throughout, one finds figures, data of all kinds, and tables and photographs of typical laboratories as a basis for further discussion and investigation. In the final chapter, thirty-one suggestions of possible definite actions are made, ranging from joint industrial/school associations to long-term currieulum research. Two particularly interesting lines of argument emorge. One is that it was everywhere insisted by schools who have begun applied science courses that this was done for educational reasons rather than vocational reasons (although some comment in Scotland was less altruistic). The Crowther Report suggested that for many schoolchildren, the 'alternative road' to interest in sciontific and technological matters is the most attractive one, and in many cases it has been stated that applied science has been introduced to make school science in some way less dull. Generally, it is true to say that there has been in the past, and still is, in school courses, a pre- 
ponderance of analytical rather than synthetic or creative work, a tendency to measure an effect rather than to make use of it; new courses, especially, say, those of the Sevenoaks type, can be more properly regarded as introduced to redress this lack of balance. This kind of response may automatically help to foster the kinds of attitude one would look for in successful engineers, but has not specifically been introduced for this purpose.

Yet, secondly, a good deal of play is made of the reluctance of headmasters to accept that the 'alternative road' into a scientific career might be the best one for some of the best students. This necessarily brings to mind many thoughts about educational attitudes in the country, and the concern of engineers with their own 'public image', especially in the eyes of science teachers counselling boys and girls when they consider university courses. If one considers the diversity of activities under the broad head of engineering and technology, it is perhaps not too surprising that this image is a little out of focus, but the present careful expositions of the need for flexibility, breadth and social and economic awareness in an engineer may alter this. If a teacher is able to consider an engineer as a bridge-builder between two cultures, rather than a glorified technician, he can then be more inclined to satisfaction at the prospect of the best intellects entering engineering careers. The objections by a number of authorities to the idea of A-Level examinations in applied science make good sense when one considers the present,-day attempts to ask for more flexible university entrance requirements, and the talk of a single chemistry- physics A-Level subject. At the same time, the investigations of approaches to technological studies at sixthform level and the centralization of such work by the Schools Council are very welcome. What seems vital is that any teaching institution should be concerned, within the general framework of science courses which its size and resources allow it to offer, to present as wide a picture of what the whole effort of seientific and technological work consists of, as is possible, whether this be through complete courses in large schools, or project work, or re-orientation of existing pure science into application-conscious treatment. This is particularly true, if like the Nuffield Scheme co-ordinator, one regards a sixth-form course as being a final chance to sample disciplines; it will be of very great interest to see the eventual content of the Nuffield A-Level courses. Help which can be obtained, through eurriculum research of any kind, for example, is obviously most important in all circumstances.

In any event, the Page Report, making available detailed information, opinion and informed suggestion, is a key document for anyone concerned in decisions about school seience courses. In addition, it is eminently readable, and, despite the rapidity of its publication, excellently produced. It is possible that it may be the preliminary to further substantial changes in school work, and it will certainly help the careful thinking about this rather complex subject which is needed while school science is altering at the present rapid rate.

T. A. BurdeTt

\section{CHEMICAL PHYSIOLOGY OF THE ACID MUCOPOLYSACCHARIDES}

A LTHOUGH there have been several excellent symA posia on connective tissues, it is now too big a subject to cover adequately in a meoting of manageable size, and its various compartments tend to be treated separately. The acid mucopolysaccharides have been quite fully discussed from the metabolic and chemical aspects, but not often from the point of view of the chemical physiologist. This is not surprising, since the state of combination of acid mucopolysaccharides in tissues was unknown, their localization dependod on primitive and non-specific techniques, and practicaliy nothing was known of their molecular biology. Considerable progress is being made on all three problems, and it was thought that the results would support a three-day meeting, with ample discussion.

The symposium was organized by Dr. Giuliano Quintarelli, of the University of Alabama, and held under the auspices of the Carlo Erba Foundation in Milan during September 23-25. Travel grants were made available by American Chicle Co. and Colgate-Palmolive Co. through Dr. J. Volker, vice-president of the University of Alabama Medical Center.

Seventeen speakers were invited, several of whom comprehensively reviewed their subjects in addition to presenting new data. Dr. Helen Muir (St. Mary's Hospital, London) opened the proceedings with a paper on "Protein-Polysaccharides", and was followed by Dr. L. Rodén (University of Chicago) on "The Protein-Carbohydrate Linkages of Acid Mucopolysaccharides". Dr. Rodén presented the evidence that chondroitin sulphate $A$ is linked to protein by means of a glucuronosyl-galactosylgalactosyl-xylosyl-serine bridge, with much detail on positions of glycosidic bonds, etc. Dr. P. Hoffman (Research Institute for Skeletomuscular Diseases, New York) discussed threonine, serine and asparagine as alternative linkage points for the polysaccharide at the protein. Dr. Hoffman took up a theme introduced by Dr. Muir (frequently mentioned during the meeting) as to how heterogeneous the cartilage protein-polysaccharide is, and showed that his preparations contained chemically dissimilar fractions, separable on electrophoresis.

Papers by Dr. Castellani (Pavia) and Drs. Pedrini and Pedrini-Mille (University of Iowa) dealts with the keratansulphate-protein complex from epiphyseal plates and human costal cartilage, respectively. Dr. Pedrini reported three components in his water extracts, as shown by electrophoresis on cellulose acetate, the slowest being predominantly the keratansulphate complex, and the fastest the chondroitin sulphate complex. The ratio of the slowest to the fastest increased with age. They differed significantly in their amino-acid content. Dr. J. D. Gregory (Rockefeller University, New York) described countercurrent fractionation of the hyaluronidase digested cartilage protein-polysaccharide. Two components were isolatod, one containing the keratansulphate, and the other remnants of chondroitin sulphate attached to protein. Dr. N. di Ferrante (University of Texas), in the course of a review of the "Antigenicity of the Protein Polysaccharide Complexes from Cartilage", presented evidence that the keratansulphate-protein fragment of Dr. Gregory possessed the antigenic properties of the original proteinpolysaccharide. The second fraction of Dr. Gregory, containing remnants of chondroitin sulphate, was not antigenic.

The papers of Dr. S. M. Partridge (Low Temperature Research Station, Cambridge) and Dr. D. Dziewiatkowski (Rockefeller University, Now York) dealt with the effects and the isolation, respectively, of an enzyme prosent in cartilage which proteolytically degrades the proteinpolysaccharide. The implications of these findings to the study of the complex are great, and probably much of the work already done will have to be reassessed. Dr. Cifonelli (University of Chicago) rounded off this section by pointing out areas in which chemical investigations had turned up conflicting data, and discussed degradative techniques which could resolve the difficulties.

Dr. T. C. Laurent (University of Uppsala, Sweden) opened the 'molecular biology' section with a demon- 